\title{
The cultural nationalism of Halide Edib Adıvar and Lady Augusta Gregory from the aspects of gender, language and anti-imperialism ${ }^{1}$
}

Neslihan G. ALBAY²

\begin{abstract}
APA: G. Albay, N. (2019). The cultural nationalism of Halide Edib Adıvar and Lady Augusta Gregory from the aspects of gender, language and anti-imperialism. RumeliDE Dil ve Edebiyat Araştırmaları Dergisi, (17), 469-494. DOI: 10.29000/rumelide.657926
\end{abstract}

\begin{abstract}
This article demonstrates how the anti-imperial perspectives of Lady Gregory and Halide Edib shaped their sense of national identity, illustrates the ways in which they took a critical stance against British colonialism and emphasizes how their subjective elaborations and interrogations of anti-colonial nationalisms in other countries influenced their sense of "nationhood." Accordingly, I expose the similar nationalist ideals of anti-imperialist social reformers who were contemporaries of Halide Edib Adıvar and Lady Augusta Gregory, with a focus on maintaining national values and traditions as part of resistance against cultural imperialism. The transnational encounters and exchanges of Gregory and Adıvar developed their appreciation of nationalism along with a viewpoint shaped by international anti-imperialism. The article analyses the components of national identity such as gender, language, and transnational exchanges by showing how they shaped the nationalist ideas of Lady Gregory and Halide Edib. This article seeks answers to the questions of what Halide Edib and Lady Gregory contributed to the debates of nation building through cultural and literary revival, how their changing political ideas were influenced by international events and particularly transnational encounters, and what their influences were on the creation of a new identity for women.
\end{abstract}

Keywords: Feminist, anti-imperialist, social-reformer, nation-state, cultural, nationalism, identity, gender, language.

\section{Halide Edib Adıvar ve Lady Augusta Gregory'nin cinsiyet, dil ve anti- emperyalizm açısından kültürel milliyetçiliği}

\section{$\ddot{O}_{z}$}

$\mathrm{Bu}$ makale, Leydi Gregory ve Halide Edip’in anti-emperyal perspektiflerinin ulusal kimlik anlayışlarını nasıl şekillendirdiğini göstermekte ve İngiliz sömürgeciliğine karşı eleştirel bir duruş sergileme biçimlerini ortaya koymakta ve sömürgecilik karşıtı milliyetçiliğin diğer ülkelerdeki yansımalarının, onların "ulus olma” düşüncesini nasıl etkilediğini vurgulamaktadır. Buna bağlı olarak, kültürel emperyalizme karşı direnişin bir parçası olarak ulusal değerleri ve gelenekleri korumaya odaklanan Halide Edib Adıvar ve Leydi Augusta Gregory'nin çağdaşları olan benzer antiemperyalist sosyal reformcuların benzer milliyetçi ideallerini de ortaya koyuyorum. Uluslararası bir anti-emperyalizm anlayışı ile şekillenen bakış açılarının etkisiyle, Gregory ve Adıvar'ın uluslararası bağlantıları ve etkileşimleri, milliyetçiliğe olan ilgi ve alakalarını artırmıştır. Makale, cinsiyet, dil ve uluslararası temaslar gibi ulusal kimliğin bileşenlerinin, Leydi Gregory ve Halide Edip'in milliyetçi fikirlerini nasıl şekillendirdiğini göstererek analiz etmektedir. Bu makale, Halide Edip ve Leydi

This article has been adapted from Neslihan GUNAYDIN ALBAY's PhD Thesis

Öğr. Gör. Dr., İstanbul Sabahattin Zaim Üniversitesi, İngilizce Hazırlı Bölümü (İstanbul, Türkiye), n.albay87@gmail.com, ORCID ID: 00oo-0003-1933-0125 [Makale kaylt tarihi: 05.11.2019-kabul tarihi: 20.12.2019; DOI: 10.29000/rumelide.657926] 
The cultural nationalism of Halide Edib Adivar and Lady Augusta Gregory from the aspects of gender, language and antiimperialism / N. G. Albay (pp. 469-494)

\begin{abstract}
Gregory'nin kültürel ve edebi reform yoluyla ulus inşası tartışmalarına nasıl katkıda bulundukları, değişen siyasi fikirlerinin uluslararası olaylardan ve özellikle ulusötesi temaslardan nasıl etkilendiği ve kadınlar için yeni bir kimliğin oluşumu üzerindeki etkilerinin ne olduğu sorularına cevaplar aramaktadır.
\end{abstract}

Anahtar kelimeler: Feminist, antiermperyalist, sosyal-reformcu, ulus devlet, kültürel, milliyetcilik, kimlik, cinsiyet, dil.

\title{
Giriş
}

Halide Edib Adıvar and Lady Augusta Gregory took active feminist roles in the process of forming cultural identity in their emerging countries. Focusing on their roles as anti-imperialists and feminist activists, with an emphasis on their respective political struggles, this article employs a comparative study of their roles as social reformers, contributors to the cultural aspects of their nationalist struggles well as the development of the national theatres of Ireland and Turkey; while it simultaneously examines their roles as pioneers in the re-envisioning of their emerging nation-states. This article explores how Lady Augusta Gregory and Halide Edib Adivar used literature both as a means to examine the imposed ideology of English colonialism as well as other dictatorial regimes, and as a lens through it to promote a new national consciousness and cultural identity, based on their respective national heritage.

One distinctive aspect of nationalism in twentieth-century Turkey as well as Ireland was the interplay of gender and nationality, as perceived in the cultural conceptions of Turkish and Irish national identities. The early twentieth century required clashes with imperial authority and the construction of a nationstate independent from the fetters of cultural imperialism imposed upon them by foreign powers. The process by which the Ottoman Empire transitioned into the Turkish Republic required the reconstruction of the nascent nation in interaction with the contemporary international movements towards modernization, westernization and secularization. Ireland was similarly on the brink of a period of national struggle to gain her own self-determination against the British Empire.

The gender aspect of this process of constructing the new national identity in terms of Irish and Turkish cultures must be analysed critically as well as analysing anti-imperial / anti-colonial activities, and the issue of language in the twentieth century. The assertion of national identity in the postcolonial nation and the presence of the female subaltern created a tension as a result of a focus on women's rights. Halide Edib Adıvar and Isabella Augusta Persse problematized the concepts of nation and gender by dealing with the conflicts resulting from recuperating their national literatures in line with female perspectives. Nationalism also functioned as a means to the ends of improving the conditions of women and the extension of their rights. Women mostly benefited from the emancipatory principles of the nationalist movements. Lady Augusta Gregory from Ireland and Halide Edib Adıvar from Turkey were both women who struggled for the protection of their nations and national cultures in the face of imperialism, while maintaining a critical attitude towards their respective governments both through their literary works and through their real life experiences in the process of nation-building at the turn of the twentieth century. They contributed to cultural nationalism, reinforced through social and literary revivals and transnational encounters.

Focusing on the contribution of these two female intellectuals to the construction of a new national identity in their respective countries struggling for independence, this study illustrates how traditional nationalism in Ireland and Turkey was defined as masculine, and then demonstrates how these writers 
altered nationalism to turn it into another way of defence that promotes women's equal participation in the nation. Arabi and His Household by Lady Gregory and Inside India and Conflict of East and West in Turkey by Halide Edib along with Edib and Gregory's selected writings, help me assess their position as anti-imperial activists. I also investigate the ways how they took critical stances against British colonialism, and expose how their subjective elaborations and interrogations of anti-colonial nationalisms in other countries influenced their sense of "nationhood". Halide Edib and Lady Gregory were inclined to seek for freedom in unknown lands with the intention to bring it to their home country. For both, the Other has an appeal. The appeal of the "foreign" serves just as a means to their end, which is to reach national freedom and independence without being corrupted by cultural assimilation.

This study provides a new critical outlook on gendered nationalist discourses and assesses the contributions of Halide Edib Adivar and Lady Gregory to cultural nationalism for the realization of social transformation through their roles as political activists and social reformers. Both Halide Edib and Lady Gregory aimed to be the external social reformers of their country by achieving the dream of being the internal reformer in family and society. Voicing the needs of their society at a political and cultural crossroad dramatically through their plays and folkloric work, and struggling to contribute to the legitimization process of their country as a nation, Lady Gregory and Halide Edib undermined the takenfor-granted perception of "nationalism" from the masculinist view and presented a more egalitarian view of nationalism in which gender identity does not play a deterministic role.

Lady Gregory was perceived dispensable and unimportant to her mother as she was female; on the other hand, she was outstanding because of her birthday. Her mother had hoped to give birth to another son after having already given birth to four girls and four boys, and this initially led her to ignore her daughter as a child. She discovered that she was exceptional when she read the warning of the soothsayer in Shakespeare's Julius Caesar, who said "Beware the Ides of March", because she had been born between 14th and 15th March at midnight, the Ides of March (Hill, 2011: 1). Likewise, Halide would also repeat the sentence "Beware the Ides of March" to herself when she was awakened by unfamiliar and far-off gunshots on the morning of March 31, 1909 (Adivar, 1926: 277). he preference for boy babies, common to many cultures in the past that showed a preference for boys over girls, was also valid for the families and societies of both Halide and Gregory. Halide says: "before my birth, it was very much hoped that I should be a boy, and my father had vowed that he would name me, after the saint Halid [Khalid, a Companion of the Prophet Mohammed]. When I disappointed them by turning out to be a girl, they persisted in giving me the feminine form of Halid, which is Halide" (Adıvar, 1926: 98-99). Similarly, Gregory's mother was disappointed by her birth because "she liked boys better than girls and wished for more sons than daughters, and so was sorry this was not a boy."3 Despite being little welcomed at birth, Gregory was aware of the enormous potential lying within her female identity. She married Sir William Gregory, who was a former Member of Parliament for County Galway and for Dublin, and Governor of Ceylon in 1880. She travelled throughout Asia and Europe with him. After the death of her husband, she pursued an interest in literature and even decided to edit his autobiography, which she published in 1894. Her meeting with William Butler Yeats became a turning point for the arousal of her interest in theatre, which would also help lay the foundations of a national theatre in Ireland. At Coole, Lady Gregory lived among the peasantry. During her youth, she was greatly interested in peasants' folk songs and folk-stories, which she started to collect systematically, a vast reservoir of the beliefs, thoughts, customs, folk songs and tales of the people of Western Ireland. This provided her rich material fors almost all of her plays. Motivated by the desire to do something for her country, "she gradually gained 
The cultural nationalism of Halide Edib Adivar and Lady Augusta Gregory from the aspects of gender, language and antiimperialism / N. G. Albay (pp. 469-494)

an empathy with those from whom she was separated by birth, education, culture, habit, dress, manner of speaking and family allegiance, to become a nationalist (Hill, 2011: ix)".

Associated with the Irish nationalist movement and the Abbey Theatre as part of the cultural and literary movement, Lady Gregory is renowned for her plays and folklore as a seminal writer in the canon of Irish modernism. She recreated Irish myth and transmitted folklore, especially in her wonder 4 plays. Most studies written on her is restricted to her involvement at the Abbey Theatre and her connections with the leading male figures of the cultural movement, such as William Butler Yeats, J. M. Synge and Edward Martyn. However, recent research has explored her as a playwright and political activist (Bell, 2008: 12). Born into the Ascendancy class of Ireland, Lady Gregory was a member of the Protestant Anglo-Irish gentry. Born into a class that identified closely with British rule, her conversion to cultural nationalism, as evidenced by her writings, was emblematic of many of the political struggles that would occur in Ireland during her lifetime. Like Halide Edib, Gregory attempted to construct a new national identity through a more liberal point of view opposing class distinctions in the new nation. She underwent a political conversion and devoted herself to her people and the nationalist cause. "In her many years of travelling, listening, transcribing and publishing, Lady Gregory did what the first modern government of an independent Ireland did: she gave value to the stories, to the mind and imagination of Irish country people" (Gregory, 1995: xxv).

From a young age, Lady Gregory bore a rebellious nature in terms of both gender and mind. Starting her revolutionary literary life by reading the songs of Young Ireland poets from a generation earlier who had rejected their Anglo-Irish background and put their focus on common people, Lady Gregory oriented towards social idealism by integrating her self-sufficiency as a strong woman as referred by Declan Kiberd in Inventing Ireland: The Literature of The Modern Nation (Kiberd, 1996: 84). Lady Gregory's literary intimacy with W. B. Yeats stemmed from their union for a sacred cause: for the Irish literary and cultural revival. As far as Lady Gregory's first interest in politics is concerned, it dates back to her encounter with Wilfrid Scawen Blunt and her witness in Egypt to the Revolt of the Colonels led by Ahmed 'Urabi, better and contemporarily known as Arabi Bey. Kiberd portrays Blunt's influence on her: "Blunt was a horseman, a poet, and an uncommonly dashing womanizer: an English Tory landlord by background and conviction, he was, nonetheless, a supporter of independence for the colonies. Meeting him at Shepheard's Hotel in Cairo, Lady Gregory "first felt the real excitement of politics" and "tumbled into a revolution" (Kiberd, 1996: 84).

Seeking greater social and political freedom within her country, Lady Gregory took interest in theatre, language and folk literature. Her interest in politics was invigorated by the Egyptian example of national struggle for independence, particularly the anti-colonial efforts of the Egyptian leader Arabi Bey against British colonialism. Acting with a lack of trust in politics and political actions owing to the frustrating political tricks applied against Arabi by British forces, Lady Gregory elaborates:

That was the end of my essay in politics, for though Ireland is always with me, and I first feared and then became reconciled to, and now hope to see an even greater independence than Home Rule, my saying has been long, "I am not fighting for it, but preparing for it." And that has been my purpose in my work for establishing a National Theatre, and for the revival of the language, and in making better known the heroic tales of Ireland. For whatever political inclination or energy was born with me may have run its course in that Egyptian year and worn itself out; or it may be that I saw too much of the inside, the tangled webs of diplomacy, the driving forces behind politicians (Gregory, 1974: 54).

Lady Gregory wrote some wonder plays such as Three Wonder Plays (1922) (including The Dragon, The Jester, Aristotle's
Bellows, which are fantasies based on folklore and mysticism), A Book of Saints and Wonders according to the Old Writings and the Memory of the People of Ireland (1906) and The Kiltartan Wonder Book 
Lady Gregory's coming to terms with Irish history stimulated her to delve into cultural nationalism and the Irish language. She preferred to claim her place within the patriarchal structure of the national movement as a translator of Celtic mythology, a playwright, and a director of the Abbey theatre. On the other hand, a radical Irish nationalist women's organization led by Maud Gonne lasting from 1900 to 1914, Inghinidhe na hÉireann "had deliberately included within their manifesto a pledge to combat the English influence they considered so injurious to "artistic taste" (Ward, 1983: 55) as denoted by Margaret Ward in Unmanageable Revolutionaries. Ward explains how the Abbey Theatre emerged with reference to the political mission of this women's organization, to challenge the cultural oppression of British imperialism in Ireland:

\begin{abstract}
The impetus provided by Inghinidhe na hÉireann led to the formation of a professional theatre group, out of which came the Abbey Theatre. Individual members of the Inghinidhe were to join and make careers out of acting, but as a group the Inghinidhe felt that their work had been accomplished. Their efforts had shown it was possible to provide good drama; once that had been achieved, they felt free to return to their work of building up a political opposition to England's presence in Ireland (Ward, 1983: 57).
\end{abstract}

As nationalism is implicated in gender power in this century, the woman-nation ideal or figure was an inseparable feature of the revival project of Irish self-fashioning. Lady Gregory was inclined to challenge the gendered ideology of Ireland's myth of itself. Ireland was portrayed as female by both the nationalistic Ireland and the colonizing English as far as the gendering of Ireland is concerned within the cultural and political context of the late-nineteenth and early-twentieth centuries. In the early twentieth century, Ireland struggled for cultural and political autonomy from England and for the purpose of national expression Gregory relied on her literature, which would enable her patriots to communicate with each other. The drama appearing at the Abbey Theatre aimed to define Ireland and the portrayal of women were also involved in this defining process. They took part in the theatre as mothers, daughters, wives, lovers, goddesses or peasants. In the roles women played on the stage, women were representatively devoted to Ireland itself. The representation of women by the playwright or the audience in this way refers to the great nationalistic endeavours made by women for the sake of an independent Ireland in the most turbulent years of upheaval.

Related to the representation of women in a nation emerging from colonial rule, in her essay entitled "Representations of Women in the Abbey Theatre" Christina Wilson refers to "an idyllic male image of womanhood generally conservative in nature" (Wilson, 2006: 330). To be able to function within patriarchy Gregory chose to behave and think like a male because, as Cynthia Enloe remarks, nationalisms have "typically sprung from masculinized memory, masculinized humiliation and masculinized hope" (Enloe, 1989: 44). Thus, Gregory forced herself to suppress her femininity and to act with a masculine imagination, and she aimed to represent her nation through her plays and translations. Murray indicates that "the people she most admired were all strong men, not women: Parnell, Roosevelt, Shaw, Collins, de Valera and, in a rather different way, Yeats. She had little in common with radical women such as Countess Markiewicz or Maud Gonne. They were never invited to Coole. She stood up to Annie Horniman, the formidable patron of the Abbey, but she never admired her" (Murray, 1997: 56). As regards why Lady Gregory deserves our attention today, an opponent of colonialism at an intellectual level from an earlier date, Gregory is recognised as "as much a rebel as any one of her detractors" (Kopper, 1976: 138), while in 1910 Shaw called Gregory both a "born playwright" like Moliere and "one of the most remarkable theatre talents of our time" (Laurence and Greene, 1993: 63). From the feminist perspective, it can be thought that "hers is a gender-based art", Murray expresses (Murray, 1997: 55). Una Ellis-Fermor concluded her chapter on Gregory in the revised edition of The Irish Dramatic Movement with the declaration that Gregory's literary contribution was 
The cultural nationalism of Halide Edib Adivar and Lady Augusta Gregory from the aspects of gender, language and antiimperialism / N. G. Albay (pp. 469-494)

'characteristically feminine': it provided 'the means or the medium by which men[sic] of genius could realize themselves'(Ellis-Fermor, 1954: 162), while it is asserted that 'her political unconscious was matriarchal' (McDiarmid and Waters 1995: xii).

In Gregory's outlook on the social position of women, the woman is regarded as saint and inspirer of men as in the Victorian idea of woman as the angel in the house. In her play Grania, which deals with the relations between the sexes, Gregory uses a feminist voice, through which she makes a study of a woman idealised and reflects the woman as the spiritualising force in a male-dominated world. Among her wonder plays, Aristotle's Bellows is a political allegory that reflects women as the agents of change according to Gregory's conservatism. Dave is a play that champions woman as the spiritual regenerator of brutalised and colonised Ireland. According to her political viewpoint, Gregory called for a republic or a "commonwealth". The Story Brought by Brigit (1924) is a symbolic allegory that embodies Gregory's prayer for peace and an attempt to knit into Irish culture, through the local witness of Brigit as well as the overcoming of imperialism by Christianity, and the woman's role in the last stages of colonised Ireland. Drawing the different portraits of the emblematic national female in her plays, Gregory contends that women played complementary roles as the spiritual and inspirational agents of revolutionary change in the patriarchal structure of the early twentieth-century Ireland for the maintenance of peace in the face of British imperialism. She chose to exploit Irish folklore and mythology and the mythological women as a means to create an Irish literature. "She believed that women should put men first, or at least be seen to, and so she concealed some of her successes and made her presence felt indirectly. She made no public statements about the role of women in society, and lived her life as though there was no need for change. Yet in several of her plays she demonstrated an interest in questioning traditional female roles, and she explored the lives of strong men" (Hill, 2011: ix-x).

When examined biographically, both Halide Edib and Lady Gregory have striking similarities in terms of similar character traits and similar life experiences nourished by the sense of nationalism. Halide Edib Adıvar was born in 1884 in Istanbul to an elite, well-educated family. Adıvar was the daughter of Mehmet Edip Bey, private treasurer of Sultan Abdülhamid II. Her mother died when she was young. She received private tutoring from well-known personalities in the field of Philosophy, Mathematics, and Social Sciences. She was sent to the American Girls College in Üsküdar from 1899 to 1901, and she became the first Muslim Turkish girl to graduate there. After she graduated, she married her tutor Salih Riza Bey in Istanbul in 1901. The couple had two boys, named Ayetullah and Hikmetullah. After 1907, she started to publish articles in the newspaper Tanin under the pen name of Halide Salih. When Salih Riza Bey chose to take a second wife in 1910, she decided to divorce him. In 1918 she married Adnan Adivar. As Dr Adnan was a member of the reformist Committee for Union and Progress, Halide was drawn into involvement in nationalist activities. On May 16, 1919, Halide was the first woman speaker at a mass meeting in Sultan Ahmet, Istanbul, protesting the occupation of Izmir by Greek armed forces. This established her reputation as a national hero for her defence of national liberation and justice. With her passionate public speeches, Halide transformed into a more prominent figure. After the occupation of Istanbul by the British in March, 1919 she fled to Anatolia with her family to join Mustafa Kemal's forces as one of the leading female heroes of the national struggle. She was promoted to the rank of "sergeant". She rejected dictatorship and broke with Atatürk after the War of Independence.

Having a rebellious nature like Lady Gregory, and being a versatile author, whose name was associated with literature and politics, Halide Edib Adivar maintained that love and freedom should be regained every day for the sake of the absolute independence of a nation (Adıvar, 2011: 333). Ayşe Durakbaşa in Halide Edib: Turkish Modernization and Feminism states that "the dynamics of a dispersed empire and 
the creation process of the Turkish nation urged Halide Edib to be both a nationalist and feminist simultaneously" (Durakbaşa, 2000: 29). Distinguishing Halide Edib as "although not the first, the most prolific Ottoman-Turkish woman writer, with twenty-one novels, four short story collections, two dramas, four scholarly works and a two-volume autobiography in An Epic For Peace" (Adak, 2004: v), Hülya Adak underscores Halide Edib's active political involvement and signals to her fluctuating political ideas in different time periods:

\begin{abstract}
During 1908 to 1918 , she was close to the Unionist [CUP] circles; for the next three years, she was part of the National Army; and from 1923 to 1925, she formed part of the opposition to Mustafa Kemal's Republican People's Party. In 1950, she served for one term (four years) as a Member of Parliament. Edib's political involvement had a significant impact on her work, while securing her national as well as international fame (Adak, 2004: vi).
\end{abstract}

One of the principal agents of the Turkish nationalist movement, Halide Edib played a major role in structuring the profile of a "new nation" and a "new woman" during the formation process of the Turkish Republic, both as a visionary and an activist, like Lady Gregory. Exalting women as nation-builders, Halide Edib demonstrated that women's restricted role in the domestic sphere was extended through their active involvement into politics by subverting the sheer division between gender roles. As denoted by Emel Sönmez in The Novelist Halide Edib Adıvar and Turkish Feminism,

\begin{abstract}
historians used to be primarily concerned with wars and military operations, but recently they have become equally concerned with the part played by individuals, both men and women, in the evolution and development of the cultural and social life of societies. To this group of individuals belongs our chosen novelist Halide Edib Adivar (1884-1964) whose active role as corporal then as a sergeant in the Turkish War of Independence (1919-1923), and as a novelist fighting with her pen for the emancipation of women is known the world over (Sönmez, 1973: 6).
\end{abstract}

In this study we cannot ignore Halide Edib and Lady Gregory's contributions to cultural nationalism through language and translation. In Edebiyatta Tercümenin Rolü (The Role of Translation in Literature: 1944), Halide Edib Adivar observes translation studies during the period of the early Republic, and refers to the fact that translation studies were more intense at that time than during the Constitutional period. Through a comparison of Turkish translation studies with British translation studies during the Elizabethan era, Halide Edib asserts that English translation studies played a substantial role in the greatest age of British literature by enriching the literary material, although she also observed there were some points open to criticism in the translation studies of both English and Turkish literature. Adıvar was pleased with the prospective result, although she foresaw some imminent criticisms for Turkish translation studies and believed that although Turkish literature seemed to have lost vitality, these translation studies would assist the birth of a more creative literary age. She herself translated some English books into Turkish, including George Orwell's Animal Farm, Shakespeare's Hamlet, Antony and Cleopatra, As You Like It, not to mention translations of her own works from Turkish into English. She contended that translating from various sources may gain the Turkish nation a very rich literature in terms of gender, but if it cannot find a way to harmoniously blend these opposite tastes, opinions and styles with their own indigenous styles, an anarchic rift may emerge in intellectual and art life, and produce a verbose, clamorous and valueless literature.

Similarly, Lady Gregory translated Irish stories, myths and tales as part of her project of cultural nationalism. However, Halide concentrated on the present more than the past contrary to Gregory who concentrated on the Irish \&Gaelic historical past. Adıvar points to the local soul, national resources and national heritage from the whole of Turkish history and literature as the essential way of solution to overcome this imminent danger. As in Lady Gregory's view of art, we observe that the nationalism of the 
The cultural nationalism of Halide Edib Adivar and Lady Augusta Gregory from the aspects of gender, language and antiimperialism / N. G. Albay (pp. 469-494)

peasantry is superior to the nationalism of intellectuals in Halide's sense of art. Halide encourages reading especially the translations of literary works that have appeared in intellectual and art sphere. Moreover, she suggests reading old or new Turkish texts as well as translations by selecting a few of them according to taste and carrying them when going out in a reference to the British intellectuals who mostly read the Bible and Shakespeare and carry them with themselves. By this, she stresses the need to give much more significance to the national culture in the face of these rich but miscellaneous materials. She indicates our duty is to form a completely new orchestration out of these materials, not a rumble.

Accordingly, Lady Gregory strives to demonstrate the richness of the local languages like Irish and Gaelic by making translations from the folk stories, folk poetry or folk songs that maintained their existence in the oral or written tradition. Through her role as folklore collector, she highlights the crucial importance of preserving the tradition of folk learning and exposes the precious treasure hidden by the efforts of cultural imperialism. In Celtic Revivals: Essays in Modern Irish Literature 1880-1980, Seamus Deane asserts: "language-always a crucial issue in a country which has had its own language destroyed by a combination of military and economic violence and another imposed by a coercive educational system [...] Irish literature tends to dwell on the medium in which it is written because it is difficult not to be self-conscious about a language which has become simultaneously native and foreign" (Deane, 1985: 13). In the latter decades of the nineteenth-century, "Ireland began to become more articulate about the central psychological aspect of the colonial problem-the contradiction of living politically as if it were one thing while culturally knowing itself to be another" (Deane, 1985: 12).

Lady Gregory and Halide Edib favoured cultural nationalism as an essential vehicle of transformation in the process of westernization and modernization. They aimed at the creation of a distinct national culture, which refers to the first argumentative question related to Halide Edib's and Lady Gregory's contribution to the debates of nation building through cultural and literary revivals explored in this study. Therefore both writers followed the policy of turning back to cultural essence to help their nations acquire their political independence and to repossess their national culture and identity by a conservatist ideology/mind-set. I describe it as conservatist, by which usage I mean to draw a distinction between these views and being conservative, or being willing to protect cultural and national values based on a shared cultural heritage for the sake of a genuine national unity. I analyse their understanding of cultural nationalism through the components of national identity such as language, gender and transnational exchanges. By stressing the importance of language, gender and transnational exchanges for nationalism, I explore how it shapes the idea of nationalism. Cultural nationalism intends to restore communal solidarity and cultural nationalists aspire to revive a distinctive community. To legitimate Ireland and Turkey's status as a distinct nation in the struggle for separate identity the revolutionary intellectuals of both countries attempted at restoring the archaic past of their nation.

Lady Gregory and Halide Edib argued that social conformity with the movement of westernization is possible only with the equal participation of men and women in cultural and political life fostered by the education of "women" and clinging to "native language". Some research focuses on the vital relation between language and culture that is essential to the maintenance of national identity. While some of the more popular work of this type, such as Jale Parla's The Wounded Tongue: Turkey's Language Reform and the Canonicity of the Novel (2008) and G. Timothy McMahon's Grand Opportunity: The Gaelic Revival and Irish Society, 1893-1910 (2008), lacks a critical dimension, the emphasis on the revival of simplified, pure native language as the emblem of national identity in these works has nevertheless been valuable in fostering research into and in emphasizing the need to see women's 
participation in literary and political life. They both use similar methodologies in their works by giving great importance to the close relation between language and national identity and to women's active participation in social life and the elevation of their status in society as it was significant not only as the identification of the 'missing sex' with the patriarchal system but also as a significant signifier of a more liberal and democratic social order.

Through the end of the nineteenth century, both writers tried to find different ways to integrate their experiences in political life with their literary background as a prop to cultural nationalism. Acting with nationalist feelings, both female writers handle nationalism as the main theme of their writings. Both writers also have the experience of cultural encounters between the East and the West as well as being multi-dimensional historical figures in their era of turbulent change. Lady Augusta Gregory and Halide Edip Adivar assumed masculinized women roles to overcome the national crises, to address the social ills within their countries, and to make this national and political struggle as the core of their works. In a way, they defied codified gender roles to challenge foreign domination in cultural and political sphere. These modern women reformed society by their prominent positions in intercultural exchanges between the East and the West. Both female authors go beyond the social requirements of being a woman and appear as "androgynous heroines" thanks to their masculine roles to be able to serve their nations as sincere patriots.

Halide Edib's political idea was not the same at all times owing to the influence of the turbulent and fluctuating political life in Turkey over her. The Turkish Corps gave halide Edib Adivar the title of "Holy Mother of Turkism" in the period of constitutionalism. She wrote Turanic novels such as Yeni Turan and Raik's Mother, and defended a liberal ideology based on decentralization. In the period of the early Turkish Republic, she followed a Kemalist and Turanic policy. Following her return from travels, she was a humanist. She was a mouthpiece for the Turkish nation overseas, and was seen as an epic hero. For her nationalism was a means to liberal humanism. Halide Edib's intellectual influences include such prominent thinkers as Henry W. Nevinson, Mahatma Gandhi, Bertrand Russell, Yahya Kemal and Isabel Fry.

Lady Gregory was a thoroughly a rebellious nationalist. She stood out with her masculine way of thinking and behaviour. Kiberd stresses: "her closest collaborator, W.B. Yeats, would respond warmly to her androgynous style, singling out her "masculine imagination" for particular praise" (Kiberd, 1995: 84). As also reflected in the spirit of postcolonial literatures, Lady Gregory, who devoted herself to reviving Irish culture and literature, was writing back to the empire by means of her translated works. Writing in the language of the oppressor, (the empire or 'centre' in other words) was crucial to Lady Gregory to make the voice of the oppressed Irish heard. On the other hand, based on her rebellious nationalist identity, Halide Edib's anti-imperial stance in her translated works was a challenge to the oriental image of the superior West constructed within the European imagination as a result of a polarisation between the East and West, while her masculine stance was a reaction to the patriarchally constructed identity of femininity and masculinity.

Nationalist movements, cultural tensions, and the woman question are the primary themes that constitute the core of both Adıvar and Gregory's literary works and inform their roles as social reformers, contributors to nationalism and the development of theatre and pioneers in the political struggles of their countries. It is only natural that both were interested in theatre because the relationship between the stage and nationalism has a long history. Theatre is a direct medium of nationalism and political activism. There is a very organic link between theatre and nationalism. The National Theatre of Ireland 
The cultural nationalism of Halide Edib Adivar and Lady Augusta Gregory from the aspects of gender, language and antiimperialism / N. G. Albay (pp. 469-494)

had a pivotal role in the politics of a new nation-state identity and in the forthcoming revolution by contributing to Irish cultural nationalism with such plays as Cathleen ni Houlihan at the beginning of the twentieth century, while the Turkish writers used theatre as an effective genre to make the public adopt the concept of "homeland" with their literary works such as Vatan Yahut Silistre (1872) (Homeland or Silistre, 1872) by Namik Kemal in the late-nineteenth century. For instance, "the founders of the Irish Literary Theatre (the precursor of the Irish National Theatre) asserted that the new theatre would no longer demean the Irish people in the way that the British theatre had done in the past" (Wilmer, 2009: 79). On the contrary, its commitment to folk and nationalistic drama was part of a project to create a new national literature for Ireland and to promote Irish culture to the world. For this purpose "Irish nationalist theatre at the beginning of the twentieth century employed historic struggles, folklore myths, and stories of idyllic rural life as a means of showing the distinctiveness of Irish (as opposed to English) culture" (Wilmer, 2009: 79), as exemplified by Cathleen ni Houlihan in which the mythical figure Cathleen calls out young Irish peasants to fight for Ireland against British rule in the 1798 uprising. Expressions of nationalism continue to shape the content of theatrical texts today, just as the theories of such philosophers as Johann von Herder shape the nationalist discourse. Exploring the relationship of nationalism, anti-imperialism and postcolonialism to theatre helps understand better the ways in which nationalists have utilized performance both to define the nation and to challenge imperialism. Up to now various artists, scholars and playwrights like Lady Gregory and Halide Edib have staged the nation and have staged national resistance to imperial authority and colonial domination.

Halide Edib was a dramatic persona in most plays in her period as a national figure as well as being a dramatist, while Lady Gregory mirrors the political conflicts between Ireland and England in her patriotic plays in a symbolic way. There is no critical research on the comparison of Halide Edib Adivar and Lady Augusta Gregory. The exploration of their works in terms of cultural nationalism is the most substantial analysis and, with its emphasis on their political struggles and contributions to war history, provides a crucial background to this study. Lady Gregory and Halide Edib deserve more attention in terms of their anti-imperial activism and perspective. They are mostly treated separately, and with their feminist and nationalist roles. An Irish playwright, folklorist and co-founder of the Abbey Theatre, Lady Gregory is a representative of a new or changing Ireland, considering her changing political views on nationalism and her roles in the process of laying the foundations of the Irish Free State (the Republic of Ireland), just as the Turkish writer and reformer Halide Edib similarly undertook a pioneering role in constructing a new Turkish Republic as a revolutionary figure. Gregory transforms from opposition to Home-Rule into a supporter of Home-Rule and a member of the Irish National Land League, from a Unionist into a nationalist; while Edib was a Pan-Turanist who defended the idea of "decentralization" and had a liberal ideology in the Constitutional Period, a Kemalist and Turanist in the Republic Period, and a humanist after returning from abroad.

Ireland was under the dominion of the British Empire while Turkey was referred to as "Ottoman Empire" in the period before national independence. As far as the effects of these empires are concerned, cultural corruption and imperialism were inevitable and this case instigated the national groups within the empire to look for their national liberation. As regards examples of anti-imperialism in the history of both countries, the 1798 Rebellion represents the Irish anti-imperial stance against England while the anti-occupation uprising known as the "war of liberation" between 1919 and 1923 represents the antiimperial stance against occupying forces in Turkey. What differentiates the two countries from each other in their struggle against the domination of imperialist powers is that the Ottoman Empire had the founder position in the formation process of the new Turkish Republic, whereas Ireland had the colony 
position in the face of the British Empire in the transition process into the nation-state position, which indicates different nationalism contexts in two countries.

When the relationship of Ireland with the British Empire throughout history is analysed, it is evident that Ireland was exposed to British colonialism both culturally and physically at first and then she transformed into the position of the Irish National State with the creation of the Irish Free State in 1922. In his Ireland and Empire: Colonial Legacies in Irish History and Culture, Stephen Howe refers to Ireland as "a sphere of ambiguity, tension, transition, hybridity between 'national' and 'imperial" (Howe, 2004: 123). Furthermore, in his well-known Inventing Ireland Kiberd defines Ireland's political, economic, cultural, and ideological domination by Britain as a form of colonialism form which the Irish gradually freed themselves by going through a process of decolonization in the decades that followed 1921:
As far as the Irish were concerned, colonialism took various forms: political rule from London through the medium of Dublin Castle; economic expropriation by planters who came in various waves of settlement; and an accompanying psychology of self-doubt and dependency among the Irish linked to the loss of economic and political power but also to the decline of the native language and culture. Although imperial rules in twenty-six counties ceased in 1921, many descendants of settler families continued to hold much land and wealth. In the ensuing decades, Ireland became part of a new world system, which saw the collapse of colonialism in most of its outposts [...] the effects of cultural dependency [yet] remained palpable long after the withdrawal of the British military: it is less easy to decolonize the mind than the territory. Such a programme was made even more difficult by the persistence of British rule over six counties of Northern Ireland (Kiberd, 1996: 6).

The 1798 Rebellion was symbolic of the Irish anti-imperial stance considering the efforts of a group of Irish Protestants to subvert the authority of England over Ireland and to assert their independence. It was the first Irish republican insurrection against Britain. Reflecting the Irish struggle for freedom and the political relations between England and Ireland, Gregory's play the Rising of the Moon deals with the struggle of Ireland to free itself from the English rule. The play symbolizes Irish independence. Written in the background of the Anglo-Irish War, this political play deals with the situation of the characters divided between the ideas of duty and patriotism during the Irish War of Independence launched against the British government in Ireland. Making a call to the people of Ireland to stay united for the sake of a unified Ireland, the exhortative play communicates the message to unite as Irishmen.

As well as being a topic of continuing interest for the cultural critic, cultural nationalism is at the forefront of literary historians as well. As W.B.Yeats expressed, "there is no great literature without nationality, no great nationality without literature" (Yeats, 1989: 30). Lady Gregory and Halide Edib endeavoured to introduce their national culture to an international platform, focusing on the conservation of national values and employing traditions to facilitate resistance to cultural imperialism while a new nation-state identity is formed. More studies on Irish literature rather than Turkish literature have been done concerning gendered nationalism. Gendered nationalism analysis done for Irish literature sheds new light on the kind of gendered nationalism that Halide Edib practiced. My reading of Irish literary tradition sheds new light on the Turkish literary tradition. Gender and nationalism are mutually constructive concepts which are intertwined. Drawing on a specific intersection of gender and nationalism, feminist scholars emphasize the gendered underpinnings of nationalism as the integral part of anti-colonial nationalist movements. The gendered manner that dominant nationalism assumes in most states all over the world was condemned to be broken apart because of the implications that it inhabited for women. Negotiating with the dominant male discourse of nationalism women wanted to be recognized as legitimate nationalists who were equal to men in their national struggles. Besides their disaffection to English authority, Irish patriots had a feeling of cultural 
The cultural nationalism of Halide Edib Adivar and Lady Augusta Gregory from the aspects of gender, language and antiimperialism / N. G. Albay (pp. 469-494)

dislocation and insecurity owing to the imperialist attitudes of the colonizer. To avoid the denigrating identity imposed by the colonizer it was essential to counteract a political and social terrain infused with a masculinized dream of nation building through feminist activism.

Due to the effects of colonization on the Irish literary system, the revival of national pride through literature was integral to most feminist nationalists. The complex interaction between gender and nation entailed the equal participation of women into the national struggle for the construction of a democratic nation-state identity. Gendered nationalism transformed into ungendered nationalism for the emancipation of women in social, political and literary spheres with the gradual appearance of women in public place. Literary exertion and political activism of women along with their endeavour to take part in national struggle and in cultural activities such as collecting folklore or using folkloric elements in their works all contributed to the emergence of ungendered nationalism which was fundamental to the radical changes and transformation in the early twentieth-century Turkish and Irish societies on the brink of political change.

In the case of Irish republicanism, this means the development of democratic and nationalist ideology was based on the idea that all of Ireland should be an independent republic, while in Turkey this meant laicism, or secularism. Because of the oppressive influence of the British administration on Irish culture after hundreds of years of Irish resistance in the face of the English presence on the island the Irish Republican ideology emerged through rebellion. The emergence of republicanism in Ireland as opposition to British rule was basically related to the anti-imperial struggle of Ireland resisting British conquest and its imperial purposes on itself while republicanism in Turkey was adopted as a system of management in order to liberate the country from the fetters of bigotry and it aimed to pave the way for other reforms and innovations as a movement of political reform as part of the Turkish Revolution. The treatment of some political, social and cultural practices such as the dressing style of women in public sphere or the adoption of a western way of life or mindset in the nation-building process by the Turkish Republic can also be explicated by the premises of postcolonialism. The anti-colonial struggle and antiimperial resistance against the preservation or imposition of colonial heritage on oppressed cultural groups became the pungent destiny of both Ireland and the new Turkish state. The instrumental role of women within the Turkish and Irish modernization projects in the construction of national identity was one of the common elements of the nation-building process in both Ireland and Turkey. Their active participation in the public sphere in different roles as well as becoming educated altered the mode of formerly constructed male-based political texts or literary works.

As Irish women were identified with the country of Ireland, the improvement of their social status was associated with an ideal order that would be restored by the nationalist writers, artists and intellectuals of the new nation-state, just as in Adivar's identification of women as state-builders, considering the institution of family at the centre of the state. Coming to terms with a Gaelic past and engaging with Irish cultural traditions enabled women writers to reconceptualise the ideas of "nation", national culture and traditions in ways that are more inclusive. Likewise, in Turkey women served as agents of nationalism and creators of the new state with a tendency to return to Turkish cultural origins or ancient values in terms of family morality in Adıvar's understanding of Turkish women's part during the formative years of the Turkish Republic. With this depiction, Adıvar challenged the ideologically determined position of women in the private realm according to her own discursive understanding of nationalism. In his book In Search of Ireland: A Cultural Geography Brian Graham explicates: "women's reflections on Irish nationhood and gender, in historical research, creative forms and critical writings within and outside Ireland, do not simply criticise dominant ideas of nationhood but offer new 
ways of thinking about Irish history, gender and cultural belonging" (Graham, 1997: 111). Therefore, women's reconceptualization of national ideas or culture has as great appeal as their collaboration in nationalist resistance in different roles for the repossession of national identity.

The role of gender, especially the representation of women as the inner essence of the nation 5 started to change and take a new direction during the period of cultural nationalism. Women were also called upon to sacrifice themselves on the battlefield for the motherland as the defenders of the national community like men. According to Halide Edib, a new outlook on women emerged and women were no longer relegated to the private sphere. In contrast, women reinforced Turkish nationalism. In this process of constructing a national identity, the role of intellectuals was significant, particularly in the nexus between gender and nationalism. Given the contribution of female figures to the Wars of Independence as the emblems of national collective identity, it is necessary to elaborate on the balancing effect of women in the face of masculine nationalisms. Equal rights of citizenship were the principal need of both men and women to struggle on behalf of the nation because the contributions of both men and women were necessary and significant for the attainment of national strength and independence. As freedom in any sense cannot be provided for women without gender equality in terms of social, political and cultural opportunities, the social position of women is the key to the formation of an egalitarian society in a democratic nation-state. Lady Augusta Gregory and Halide Edib Adıvar, who may also be considered unconventional in their own societies, aimed for social transformation through social activism and cultural nationalism, and approached the concept of "nationalism" from a different angle in their literary works as the requirement of their gender.

Fiction is a genre through which the most autobiographical confessions are made while autobiography is the closest genre to fiction most of the time. An individual relationship between the narrator and the main character that Philippe Lejeune identifies with "autobiographical pact" 6 reveals the author or narrator very often. On the other hand, autobiography turns into a genre very close to fiction for specific information not to be revealed (Lejeune, 1982: 216). In this respect, fiction includes truth and autobiographical features easily because it does not establish an individual relationship between author, narrator and main character, and it does not claim to represent the truth. From this point of view, Adivar's early works are presented as 'novels', but at the same time autobiographical just as Seventy Years is the autobiographical book of Lady Gregory. There are substantial similarities between the characters in her novels, for example, deceived spouses (Refika, Handan), leading women in leadership position (Kaya) in political and social struggle and Adıvar's own biography. In addition, these novels are a struggle of a woman writer for self-identification both as a woman and as a writer at the same time. These works which are structurally similar and can be described as autobiographical novels help us evaluate the problem of writing yourself at the beginning of the twentieth century (Adak, 2004: 162), particularly writing women's lives. It was highly probable to come across symbolic traces from the life stories of writers in these works. Especially if the author was female, her novels concealed a lot of private details as regards her feelings, thoughts or inner self in the way of introspection and self-assessment in a patriarchally structured society which granted women with a right to survive only within a restricted scope of social and cultural freedom. Besides, it was difficult for a woman to concentrate on the concept

Ed. David Inglis, Anna- Mari Almila, The Sage Handbook of Cultural Sociology, p.437.

According to Lejeune, the 'autobiographical pact', that is, a feature that makes a text autobiography is definitely the narrator's compatibility with the first character. Whether or not the author agrees with the narrator is not determinant. Lejeune 1982: 204-205. 
The cultural nationalism of Halide Edib Adivar and Lady Augusta Gregory from the aspects of gender, language and antiimperialism / N. G. Albay (pp. 469-494)

of woman's autobiographical self and write herself in a male-dominated society without any selfconsciousness.

Fictional autobiographies of Halide Edib are mostly reflections from her own life story no matter how distant they seem to be from her inner world with their realistic features and depictions. The use of peasant speech and characters enabled Gregory a further liberation of her emotions like Shakespeare the masculine grandeur of whose art was revealed in its original English (Adivar, 1926: 220) combined with the language of peasantry. As can be understood from the works of Halide Edib, there is an allegorical relationship between woman and the Turkish nation, just like the association of Ireland with women and feminine features. The feminine subject is subjugated to national self-determination (such as the sacrifice of Ayesha on the battlefield or the sacrifice of many young men for the sake of Ireland symbolized with the Old Woman in Cathleen ni Houlihan). Closely identified with women figures, the national struggle of both Turkey and Ireland owes a lot to the collaboration of women empowering the nation as maternal figures. Halide Edib uses a male narrator to expose her opposition to the despotic regimes, authority and patriarchal structures that misunderstand the concept of modernity and endeavour to impose this new phenomenon on the new nation. The first-person perspective preferred in The Shirt of Flame as a form of gendered resistance is the voice of the allegorical critique of Kemalist nationalism and secular modernity. In some specific points of the novel Halide Edib makes her part felt to readers as a vanguard intellectual who made a political intervention against patriarchal authority. Göknar comments: "the popular animosity toward Halide Edib as a compromised figure of Turkish letters can be clarified through a gendered reading of her work as a feminist rather than simply a nationalist subject. It is the critical, political, and gendered aspects of her work that are elided and suppressed in literary histories" (Göknar, 2013: 4-5). As a multi-dimensional writer, Halide Edib achieved to project both her feminist and nationalist side in her works adeptly even if historical discourse did not highlight her feminist features much.

Likewise, Gregory's work bears great importance as it both exposes awareness about the marginalized role of women within the national cause and defies the ways in which women are reflected as the passive defenders of the nation in patriotic discourse. Especially her plays reveal the patriarchal nature of nationalism, which both planned to exclude women from taking active roles in the formation process of the new national identity and did not give them the right to be regarded as patriots, who are depicted with masculine terms in a masculine world. Starting life from the very beginning as "a neglected and forgotten" (Kiberd, 1996: 83) baby because of her gender as her parents expected her as a boy at first and were disappointed later, Lady Gregory distinguished herself with her "masculine imagination" (Kiberd, 1996: 84). As the core of her political and literary life, she followed the principle: "to think like a wise man, but to express oneself like the common people" (Yeats, 2002: 391). Underscoring the importance of the country speech, in other words, local dialect in writing the cause of independence realistically, Yeats resorted to the support of Lady Gregory very often because of her good command of the local dialect as a person who acquired the language of the people naturally. In her paper "Lady Gregory: Exalting Folklore and Dialect as National Identity" Matilde Fogliani stresses: "Lady Gregory was the first Irish writer to use the Irish peasant language in written works. Through her groundbreaking use of dialect that was previously regarded as belonging only to peasantry, Lady Gregory recasted the values and social markers that were associated with the lower classes"7 (Fogliani, 2014: 3). This cultural work organized and carried out by Lady Gregory aimed to engrave the folklore, language, literature and traditions of the native culture in the minds of Irish people. The development of Irish

Matilde Fogliani, "Lady Gregory: Exalting Folklore and Dialect as National Identity" Journal of Italian Literature and Culture:La Fusta Devotion, Volume XXII (Fall 2014) 
cultural nationalism in the nineteenth century necessitated living among the people and observing their way of behaving, language and traditions more closely as experienced by Lady Gregory herself. In contrast to British colonialism, Irish cultural nationalism aimed to repossess Irish national identity and literature by reviving Gaelic Irish culture. Gregory's cultural work was revered and appreciated by Yeats personally because of her realistic approach in transmitting real Irish lives, Irish dialect (peasants' language) and real-like Irish characters into literature successfully, especially considering her great contribution to the writing process of the nationalist play Kathleen ni Houlihan.

Concentrating on the dialect and the cultural sphere, Lady Gregory was absorbed in the activities of rewriting the symbols of Irishness. Her enterprise to collect folklore and materials for storytelling had a feminist aspect, closely integrated with national ideals because she would change the flow of narratives and indirectly shape the historical facts by benefitting from the power of the teller. Her mission of transmitting Irish folklore and cultural values was also part of her feminist voice blended with her national aspirations. In her plays she either assigned women active roles to change or shape history like men or reflected self-awareness about the passive position of women in contrast to men within a patriarchal society like Halide Edib employing various women profiles in her novels in order to manifest her self-awareness about their particular female positions.

Ireland and Turkey needed the pen and voice of such reformist women as Gregory and Adivar as mental weapons to conquer patriarchally structured societies as well as the patriarchal frame of minds and to reinforce nationalism. Both Lady Gregory and Halide Edib were ungendered public figures that endorsed liberalism, modernism and nationalism. They were urged to be abstracted from their feminine identity to be accepted into literary world and political life. The whole world was going through a radical transformation culturally and socially with the increase of literacy rate and the movement of nationalism spreading extensively. A leading feminist figure and academic, Kumari Jayawardena correlates movements for women's freedom with national projects and states:

It is in the context of the resistance to imperialism and various forms of foreign domination on the one hand, and to feudal monarchies, exploitative local rulers and traditional patriarchal and religious structures on the other, that we should consider the democratic movement for women's rights and the feminist struggles that emerged in Asia. The country studies, in which we examine the situation of each country in detail, will show that struggles for women's emancipation were an essential and integral part of national resistance movements (Jayawardena, 1986: 8)

Jayawardana states that feminist movements arising as a consequence of resistance movements should be taken into account as they appeared in order to fill in a social gap and they are fundamental to women's liberation and national independence. According to Jayawardena's observation as regards the effects of nationalism extending all over the world, inspiring other countries with its national struggle against Britain, Ireland is the embodiment of the struggle for freedom, independence, equality, emancipation and resistance. As I mentioned before, Lady Gregory's anticolonial efforts in Ireland can be associated with her transnational connections like Halide Edib. She was influenced by cross-cultural nationalisms, primarily by Egyptian nationalism and these representations of nationalism enabled Gregory to forge new understandings of Irishness by revising assumptions about gender and race in nineteenth-century Ireland. Transnational alliances or exchanges incited her to endorse women's political activism. Her feminism was inclined to be concealed while her nationalism was enunciated evidently in her plays. Likewise, Halide Edib's political views and outlook on life were shaped and varied as a consequence of her cross-cultural interactions and transnational alliances. Outside Turkey Halide Edib defended the national freedom of her country, women's emancipation and the intermingling of materiality with spirituality, which would bring about other social, cultural changes and liberties for all 
The cultural nationalism of Halide Edib Adivar and Lady Augusta Gregory from the aspects of gender, language and antiimperialism / N. G. Albay (pp. 469-494)

humanity. Halide Edib symbolically handled the theme of "freedom or women's liberation" in her novels as well as giving it a special place in her life as the cause of struggle in political, social and cultural spheres.

Writing a series of articles on education, Halide Edib's idea of westernization centres upon the education of women, which totally changes the family structure in society by increasing roles for women in social and political life. Halide Edib's sensitivity to woman's education relates to her conception of women as teachers that will transfer national culture to their children. According to Halide Edib's mindset, women are essential to the radical change of society. In addition to the need for improvements in order to ameliorate and equalize the status of women with men in social, political and cultural sphere, it was necessary for women to take active roles in professional life. As an example of the social transformation of women's roles, in Halide Edib's Yeni Turan it is remarkable that women assume roles as socially responsible teachers and orators, while the heroine, Ayşe is the symbol of a national entity which has been moulded by the western culture in Ateşten Gömlek. In a sense, Ateşten Gömlek gives the message that the nation cannot be formed without women who instils the feelings of passion, love and struggle in men. Inci Enginün stresses that love for nation and love for the woman representative of freedom became the second shirt of flame of men (Enginün, 2007: 421). Women are catalysts who stir up the liberal ideas of men in the defence of national ideals at the expense of personal feelings.

The literary works of Halide Edib and Lady Gregory have helped me (and in particular Halide Edib's The Shirt of Flame, The Turkish Ordeal and Gregory's Our Irish Theatre with her wonder and folk history plays) to find out if these writers exhibit a local or international outlook of anti-imperialism and how their experiences of war affected their political views and status as anti-imperialist, political activist, social reformer and cultural nationalist. Both writers played a significant role as the external social activists by being the internal reformers within family and society. Despite coming from different cultural backgrounds Halide Edib and Lady Gregory shared similar ideas as the products of their time. Both writers followed a folk-based strategy in their literary life to consolidate the new social order and the new nation-state in the early-twentieth century. In addition, Halide Edib's sense of nationalism is not expansionist but humanist and liberalist like Gregory's. As in Lady Gregory's view of art, we observe that Halide Edib's art esteems the nationalism of peasants over the nationalism of intellectuals. As a woman who wanted to serve the people, Halide Edib was of the opinion that "a craftsman is, first of all, the child of the land where his roots are buried but at the same time he is the servant of justice, people and truth" (Adivar, 1937: 9) ${ }^{8}$. To establish solidarity with the people Gregory regarded learning and speaking Irish fundamental to her studies on cultural nationalism just as Halide Edib considered it crucial to acquaint herself with folk stories/dialects.

Gregory and Adivar's cultural nationalism necessitated living among the people to witness their way of life and traditions more closely and it aimed to repossess the national culture and identity. The gendered discourse and the gendering of Ireland were created as a consequence of some racial categories and gender stereotypes formed to justify British colonization and imperialism. Because women contributed to war history in various roles, they needed to have the same social and cultural rights with men. The intersection of gender with national identity was essential to reassert both Irish and Turkish cultural heritage. Particularly, women's support of the national cause in accordance with the same national aims and ideals like men cannot be underestimated. With a focus on the dialect, folklore and cultural work Gregory and Adıvar aimed to rewrite the symbols of Irishness and Turkishness respectively.

Feyza Hepcilingirler, Halide Edib Adivar: Halka Dogru, p. 239 
Although they have been restricted by gender stereotypes and the gendered discourse of nationalism throughout history, women's contribution to nationalist politics is crucial because of the parallel progress of nationalism and feminism as the embodiments of national collectivity. Owing to their gender and the unconventional positions, they embraced within their societies Gregory and Adivar endorsed social transformation through cultural nationalism and offered a new outlook on the concept of nationalism. Through their literary works they aimed to change women's consciousness and to encourage them to fight for their own demands through participation in political activities.

Their cultural work was highly integrated with feminist and national ideals as they would change the way of chronicling and fictionalizing historical facts, narratives or representations of gender, which were socially determined and stereotypical. Through literature, both writers were inclined to assign women active roles by increasing their self-awareness about their oppression in a patriarchal society. Adivar and Gregory were inclined to use a gender-neutral language in their works and forced their way into social and cultural life by abstracting themselves and their fictional characters from their feminine identities. Witnessing cross-cultural events of nationalism and having transnational connections led both writers to forge new understandings of gender and race in the late-nineteenth century Ireland and Turkey. They endorsed national freedom, women's emancipation, cultural traditions and further liberties for all humanity.

Considering that the rural-intellectual divide that can be seen in their works is a central fault line in Gregory and Adıvar's sense of nationalism, Gregory and Adıvar go beyond gender differences to identify it as the equally important aspect of their national cause. One of the leading figures of the Irish Celtic Revival at the beginning of the twentieth century Lady Gregory strived to elevate the oral literature of Ireland to the medium of written prose for the sake of a new national establishment. She was lucky as she had a Gaelic-speaking nurse in Roxborough. This enabled her to be exposed to the Irish folklore, traditions and the Gaelic language. Her charity work in small villages before starting her career to contribute to Irish literature helped her a lot to observe and collect Irish folklore as an integral part of daily life closely. Celtic beliefs that were preserved in the Western coasts of Ireland maintained to survive in colloquial Gaelic. Through her retellings and narrations, Gregory aimed to bestow prestige upon Irish identity and culture in danger of corruption under British hegemony. The underlying reason why she used Irish folklore as the prevailing theme of her writing was to elevate the Irish language into the international stage by strengthening the Irish identity and dignity. The focus in her literary works was Irish people and their language rather than Irish folklore directly. While Gregory concentrates on folk traditions in her works such as Grania, Kincora and Devorgilla; Halide Edib also made use of folk traditions in her plays and works such as Tatarcik, Sinekli Bakkal (The Clown and His Daughter) and Masks or Souls.

As with Gregory's treatment of Irish folk figures, Adıvar's treatment of Turkish folk figures such as Nasreddin Hodja referred to her romantic vision of folk tales, stories or jokes, as profound expressions, and humorous understanding of, the human condition. Both writers collaborated in mythmaking combined with fantastic elements, in particular using local dialect in their works or making translations. The influence of Shakespeare, Shakespeare's plays or his theatrical traditions on their writing styles is clear. The world of theatre had great impact on the life philosophy and political views of Adivar and Gregory, and played a pivotal role in the formation of a new nation-state identity in Turkish and Irish politics. Due to the close relation between theatre and nationalism, Turkish and Irish nationalists, be they playwrights or performers, utilized plays to define the nation and to stage national resistance to imperial domination. A prominent leader of the Irish Cultural Renaissance, Lady Augusta Gregory made 
The cultural nationalism of Halide Edib Adivar and Lady Augusta Gregory from the aspects of gender, language and antiimperialism / N. G. Albay (pp. 469-494)

efforts to establish an anti-imperialist Irish national theatre, the Abbey. As well as being popular for her redaction of Irish epics as a folklorist, Lady Gregory was well known for her history plays that popularized old Irish myths. Her politically engaged plays mirrored a popular anti-imperialist attitude towards British imperialism.

Lady Gregory and Halide Edib alike contributed to their national theatre. As co-founder of the Abbey Theatre, Lady Gregory took part in some performances of the plays she co-authored with W.B.Yeats, as a symbolic marker of a new or changing Ireland. Her involvement in the Abbey gave support to the development of Irish nationalism as well as the development of her own artistic talent, since theatre enabled Gregory to work for the people and educate them for the reassertion of Irish cultural identity through political change by telling their stories on stage. Her devotion to the Abbey theatre was concerned with the significance of the Abbey Theatre for the cultural movement and as a powerful agent of regenerating the country. Instilling people with the idea of Irish autonomy through theatre was one of her principal objectives to achieve as both a dramatist and a theatre manager who geared towards cultural nationalism after her political conversion. On the other side, Halide Edib, who wrote an opera libretto called "Kenan Çobanları" (Shepherds of Canaan) and a play called "Maske ve Ruh" (Masks or Souls) besides two lost theatrical texts during her long life, contributed to Turkish theatre as actor, player, translator, director and critic as well.

Like Adivar, Gregory explored the social and cultural life of peasantry, tried to learn the native language in order to collect the folklore, myths and stories in old Irish. She aimed to revive the Irish language through cultural nationalism and took an opposite stance against British imperialism in the late nineteenth, early twentieth century Ireland. Despite her Anglo-Irish background, she criticised the hypocrisy of British colonialism and took a nationalistic stance in support of Ireland under the dominion of Britain. Gregory's plays raise the awareness of women's marginalized role and position within the cause of Irish nationalism while her representative role is reverberated in her nationalistic plays. Gregory aimed to make Irish history alive in the popular imagination by reinterpreting national events in her folk history plays. Liberal humanism, freedom of opinion and women's social and cultural emancipation were among the common life principles of Gregory and Adivar defending feminist nationalism.

Reflecting her interest in Irish history with her portrayals of contemporary Irish life and deeply nationalist tone denouncing the English, Gregory's plays and characters are mostly representative. Shakespeare and his literary works influenced both Gregory and Adivar in different ways. They stressed the importance of peasantry, peasant dialect language and culture for authentic Irish or Turkish identities, as a natural result of their common familiarity with Shakespearean language and traditions. They were both inspired by Shakespearean tradition of theatrical wonder and consequently they wrote wonder plays or folk-based plays, which also include fantastic elements.

Lady Gregory and Halide Edib's approach to the male-dominated historical discourse as well as their anti-imperialist struggle for constructing a nation-state identity became a significant mechanism in the configuration of feminist nationalism and in the construction of national literature. Linking cultural nationalism with social and literary revival, Adıvar and Gregory saw language as the primary step for the cultural awakening and national consciousness. Secondly, they oriented towards folklore collection among peasants. Restoring national dignity on the way to self-determination was realized mostly thanks to this collection of folklore and oral traditions. That is why they targeted at local people to reach this cultural treasure. As in Adıvar's centre of life, language, theatre and folk literature had an integral place 
in Gregory's thread of life. Both regarded theatre as a medium to add to the dignity of their nations. As part of their conservatism, they defended the revival of the native language and culture, and the idea of a return to the authentic essence. Gregory's concern for 'Anglicisation' and Adivar's concern for 'westernization' had almost the same motive: the fear of cultural corruption and deterioration of cultural heritage. To tackle this problem they believed in the necessity of Cultural Revolution and social transformation by language. Gregory and Adıvar's efforts for a national theatre in the building of a nation had deal with regenerating the country through theatre in service of cultural nationalism. Both Gregory and Adivar looked at literature as a representative platform like theatre in order to struggle against the oppressive political authority. Therefore, as a way of political defence in countering cultural imperialism, nationalism was a crucial feeling for Adıvar and Gregory in the Turkish and Irish national struggle of independence in the early twentieth century. Their focus on local language led to their contributions to the collective self-representation of their nations. Setting out from the transformative role of language for society, Adıvar and Gregory valued the connection between culture and language a lot for their nationalistic cause. Their involvement in writing plays, examination of the vernacular language, folklore and the woman issue urged them to social and innovative activism for the consolidation of the new nation-state identity.

With her play Masks or Souls Halide Edib both reflects her anti-war, pacifist stance in life and her outlook on totalitarian regimes from the perspective of the legendary Turkish comic figure Nasreddin Hodja. Referring to the pacifist aspect of her nationalism, the play questions racism, European identity, materialism and the modernization followed by non-western cultures, addressing all humanity in search of happiness. The main message of the play is that souls are eternal, while masks or bodies are temporary. Another novel reflecting Halide Edib's anti-war stance, Zeyno's Son favours national unity and solidarity while it disagrees with formal westernization because of its superficiality and incompatible aspects with Turkish customs and traditions. The novel also criticises the negative influences of the materialistic focus of the western civilization on the collapse of this civilization. Both Adivar and Gregory wielded their pen to fight back to the empire especially during the national struggle years. Another common point between these writers is the opposite manner they had against the British in their works and real life out of their political views, cultural attainments and moral outlook. Protesting the occupation of Izmir by the Greek armed forces, Halide Edib was the first woman speaker at a mass meeting in Istanbul in 1919 and she was the first public speaker to mobilize Turkish public opinion. What makes Halide Edib unique is her feature of being the chronicler of the independence war as the first-hand witness of the war front. As quoted by James E. Kitchen, Alisa Miller and Laura Rowe state in Other Combatants, Other Fronts: Competing Histories of the First World War, "in her autobiography she (Halide Edib) tried to circumvent the Turkish state's monopoly on how history should be written by offering her own story as an alternative history of the Turkish liberation struggle" (Kitchen, Miller and Rowe, 2011: 290)9. Like Halide Edib's anti-colonial stance for Turkey, Lady Gregory's anticolonial stance for Ireland can be related to her transnational connections, experiences and folklore studies. The patriotic feelings of both nationalist writers induced them to take actions against British colonial plans over their countries. The revolt against authority figures either through uprising or exiles both in Turkey and Ireland has a good deal to do with the social demand for Turkish and Irish selfdetermination.

\footnotetext{
$9 \quad$ This has been argued by Hülya Adak, 'National Myths and Self-na(rr)ations: Mustafa Kemal's "Nutuk” and Halide Edip's "Memoirs" and "The Turkish Ordeal", in Irzik Sibel and Güzeldere Güven (eds.), Relocating The Fault Lines: Turkey Beyond the East-West Divide, a special edition of South Atlantic Quarterly 102/2-3, (spring/summer 2003): 509-527.

Adress

Kirklareli University, Faculty of Arts and Sciences, Department of Turkish Language and Literature, Kayalı Campus-Kırklareli/TURKEY e-mail: editor@rumelide.com
} 
The cultural nationalism of Halide Edib Adivar and Lady Augusta Gregory from the aspects of gender, language and antiimperialism / N. G. Albay (pp. 469-494)

\section{Conclusion}

In this study I tried to redefine the emerging Irish and Turkish national consciousness in terms of the parts played by feminist and nationalist women, like Lady Gregory and Halide Edib in the creation process of the new Turkish and Irish nation-states. There was a parallelism between stressing the importance of national culture and improving women's status in Ireland and Turkey as women were a central part of nationalist movements. Coming to terms with their respective cultural past and engaging with their cultural traditions enabled both Gregory and Adivar to reconceptualise the ideas of nation. Their reflections on Irish and Turkish nationhood and gender in historical and literary research within and outside their countries both question the dominant ideas of nationhood and present new perspectives on Irish and Turkish history, gender and cultural heritage. I have attempted at showing how Lady Gregory and Halide Edib assumed gender-neutral women roles to overcome the national crises, to address the social ills within their countries, and to make this national and political struggle as the core of their works. I have discussed how these modern women reformed society by their prominent positions in intercultural exchanges between the East and the West by going beyond the requirements of being a woman and appear as "androgynous heroines" thanks to their masculine roles to be able to serve their nations as sincere patriots. I have made a comparative study of their roles as writers, dramatists, social reformers, contributors to nationalism and pioneers in the political struggles of their countries. Considering there is no critical research on the comparison of Halide Edib Adivar and Lady Augusta Gregory, I explored their works in terms of cultural nationalism with an emphasis on their political struggles and contributions to war history, by drawing on a variety of secondary sources from various research areas to connect the life stories of these women writers with the war history of their period, with the analysis of nationalism, and with the gender issue in their writing styles. By mainly focusing on the roles of women in the national process as anti-imperialists, I analysed the works of Lady Gregory and Halide Edib from a distinctive angle that integrates literary analysis with the study of cultural reception to provide a better understanding of the cultural significance of these political works in their own day.

Their national cause puts cultural nationalism into the core for the transformation of society in the nation-building process with the equal cooperation and participation of women with men in political, social and literary world. Both writers desired the attainment of a new national identity with the defense of a freedom-based national policy under the impact of transcultural encounters. In a way, their case reflects that they employed nationalism as an act of self-defence for the protection of the distinct characteristic features of their nations against the restrictive bonds of imperial forces. Thus, this article attempts an analysis of how anti-imperial stances of Lady Gregory and Halide Edib influenced their representative roles in the construction process of a new national and female identity against empires. I examined the reasons how both Lady Gregory and Adıvar favored cultural nationalism as an essential vehicle of transformation in the process of westernization and modernization for the creation of a distinct national culture with the policy of a return back to cultural essence to help their nations acquire their political independence by a conservatist ideology/mindset.

Surviving in conjunction with literary and cultural revivals and radical changes in art and society, Irish and Turkish cultures have been reshaped in the context of gender, anti-imperialism/anti-colonialism and language in the twentieth century. Putting stress on the significance on transnational encounters in the development of new forms of feminist nationalism, Halide Edib and Lady Gregory reinforced their sense of nationalism and anti-imperial stances with their real-life experiences worldwide. Acting with a conservatist ideology, both writers favoured the policy of a return back to cultural essence. Their 
conservatism was in line with their transnational outlook, which was open to new influences. For the legitimization of Ireland and Turkey as distinct nations, both writers played the role of revolutionary intellectuals and social activists aiming to restore the archaic past of their nations. They are striking with their gender-neutral literary language and rebellious female nature, which may be considered a reaction to the patriarchally constructed identity of femininity and masculinity.

Halide Edib and Lady Gregory are similar to each other in terms of their roles as social reformers, pioneers in the national struggle and contributors to the world of theatre. Lady Gregory primarily put three things into the center of her life; language, theatre and folk literature. An idealiser of the peasantry, and a major cultural figure in Irish cultural history, Lady Gregory furthered her studies in the Irish language and gathered and translated folk stories from the Irish-speaking peasants in the West of Ireland, which served cultural nationalism, made important contributions to the Irish Revival and enabled a resurgence of Irish drama and poetry. On the other side, a prominent novelist, journalist, nationalist and social activist, Halide Edib played a pioneering role in the emancipation of women in Turkey, especially in the Young Turk and early Republican period. As an ardent patriot and political leader for women's rights, she became actively engaged in the cultural, social and literary movements of the new Turkish nation following the Young Turk Revolution of 1908 and the demise of the Ottoman Empire in 1918.

Lady Gregory and Halide Edib's approach to the male-dominated historical discourse as well as their anti-imperialist struggle for constructing a nation-state identity became a significant mechanism in the construction of national myths and symbols throughout the nineteenth-century Europe and Turkey. My aim in writing the present article was to contribute a comparison of these writers defending "free opinion" and freedom in nationalist discourses and political skirmishes reversing the influence of gender and foreign powers through language has contributed a new perspective to Critical Cultural Studies. I have contributed to this field by providing a new critical outlook on gendered nationalist discourses and to assess the contributions of Halide Edib Adivar and Lady Gregory to cultural nationalism for the realization of social transformation through their roles as political activists and social reformers. I have found out how both writers endeavored to introduce their national culture on an international platform with a focus on preserving/sticking to national values and traditions as part of resistance against cultural imperialism during the formation process of a new nation-state identity.

Both writers opposed empire in favour of the construction of a new national identity. Language, gender and transnational encounters are three main dimensions that influenced their nationalism. They chose to exhibit an ungendered nationalism, anti-colonial resistance and anti-imperial perspective against any oppressive power in cultural, social or political sense. Besides their feminist and nationalist roles, Lady Gregory and Halide Edib also had a pioneering role as anti-imperialists. Both intended to create a new national identity by following a liberal point of view and devoted themselves to people and the nationalist cause. They focused on cultural nationalism for social and literary revival of their countries reinforced through transnational encounters. They were critical of imperial colonization and hence they adopted an anti-imperial stance against any colonizing power in the nation-building process of their countries.

Adıvar's and Gregory's anti-war stance also share common motives including rebellion against imperial authority, foreign occupation, and cultural imperialism; along with pacifist nationalism. Gregory had concerns about 'Anglicisation' because of its alienating and corrupting effect on Irish culture while Adivar had anxiety about the westernization process in Turkey considering its negative effects that may 
The cultural nationalism of Halide Edib Adivar and Lady Augusta Gregory from the aspects of gender, language and antiimperialism / N. G. Albay (pp. 469-494)

lead to cultural decadence in Turkish society in the long process. Their criticism of western civilization is similar as both writers opposed its warring and colonizing aspect. Their perspectives on British imperialism and the new nation-state identity are similar; however, the contexts of their nations differ from each other in that Turkish nation was fighting against imperial powers (including Britain) in the position of a foundational state which was already independent while Ireland was under British control as a former colony of Britain and struggling against British rule for the recognition of their sovereignty, and particularly for the emergence of the Irish Free State.

An opponent of colonialism intellectually Gregory resisted British imperialism through cultural nationalism due to her deepening nationalist feelings. A nationalist female writer who was principally influenced by the national movements in other countries and then started to feel interest in the history of her own nation, Gregory showed her reaction to British imperialism through her nationalist deeds and literary works. Her resistance against the British was twofold considering that Ireland was a British colony before Independence and thus exposed to cultural corruption and manipulation like other countries or cultural groups colonized and oppressed by Britain. Gregory's nationalism sprouted from the outer through the inside. The transnational encounters and exchanges of Gregory and Adivar led them to gain an appreciation of nationalism in local sense with an international outlook of antiimperialism. Gregory and Adivar's international outlook of anti-imperialism along with the transnational feminist solidarity reinforced their sense of nationalism, their liberal outlook on social and political affairs and their liberal-humanist sides. Their inclination from the margins to the centre, from the outside through the inside, from the exterior to the core is indicative of their praise of local traditions within their countries as they gained awareness about the national spirit through transnational encounters and exchanges. They were writing back to the empire by their literary works. Opposition to authority was one of the common features of these two writers. Both wanted to contribute to cultural nationalism through language and translation. They put a lot of importance on local language, folk history, culture and traditions to perpetuate the self-representation of their nations. They also preferred English as an international language for the transfer of the cultural elements of their nations into other cultures easily.

Gregory creates various stereotypes about Irish people by reproducing the lower-class dialect and colloquial speech of workers as the representative and supporter of Irish culture and identity. Furthermore, through her plays Gregory reproduced ancient favourable values, such as bravery, loyalty and honesty that started to disappear in the nineteenth century prevailed mostly by rationalism and physical science. By reproducing the national masculinist discourse Halide Edib identifies the woman with the nation, that is, the one which is passive, holy and needs to be saved, while she identifies men with the nation, people and the saviour which is active. Gendered nationalism analysis done for Irish literature sheds new light on the kind of gendered nationalism that Halide Edib practiced. Their active participation in public sphere in different roles as well as getting educated altered the mode of formerly constructed male-based political texts or literary works.

Halide Edib's notion of nationalism was based on liberal humanism and the idea of balance between spiritual and material values. She believed that extreme nationalist movements are dangerous, as they forebode the end of humanity, peace and civilizations. Knowing the complicity of feminist orientalism and western feminism with colonial and imperialist projects, Halide Edib opposed the indiscriminate adoption or imitation of western values. She suggested that before accepting westernization as a form of social transformation for a new civilization, it was necessary to question the meaning of being "western". Adivar thought that if men and women could work cooperatively without gender discrimination, the 
Turkish nation and society could overcome violence, bigotry and dysfunctional education system with her self-confident individuals while struggling for national independence. She promoted the new nation and the new civilization with socially oriented women. In her view, the new nation can survive in every case with the hope of prosperity only if she does not deny her past and becomes open to change at the same time.

Closely interested in the tenets of pacifist nationalism and liberal humanism, Adivar and Gregory reflected their egalitarian worldviews in theatre; an influential way of dramatizing Turkish and Irish history, with sarcastic references to the cultural and political issues of their times. Both writers were influenced by Moliere and French literature in general. While Gregory translated Moliere, Adivar was aware of Moliere's influence on Turkish theatre and found him humane and commonsensical, particularly in comparison with other French classical writers. Adıvar's Masks or Souls reflect both Adivar's anti-war attitude and her support of the ideal of individualism and individual freedom. She thought that the harmonious union of spiritual and material values was fundamental for civilizational development. She criticised formalism and imitation in reform movements seeking to transform society. Based on the principle of liberal humanism, she endorsed social reforms for the elevation of the living standards of people in an egalitarian society that has a balanced order between its material and spiritual values and promises its individuals more freedom in terms of rights, expression of opinion and national independence. Halide Edib criticised the structure of reforms through the comments of a surprising cast of historical figures in Masks or Souls, just as Lady Gregory brought in characters or legendary figures from Irish history to criticize current Irish affairs. Halide Edib evaluated the process of westernization from good and bad sides while Lady Gregory criticized Anglicization in her plays.

Playing leading roles in the liberation of their countries in different ways, Lady Gregory and Halide Edib emphasized cultural nationalism over politics. With similar historical but different cultural backgrounds, both writers played similar roles including as cultural nationalists, social reformers, soldiers, mothers, playwrights or feminist writers. Undermining contemporary social stereotypes about women, these writers contributed to national war history, physically as well as through literature. Reflecting their dilemma between their nation and personal feelings on their fictional characters, Adivar and Gregory envisioned the new nation as an ungendered republic over the role of a 'mother'. Adivar and Gregory question idealism, love, sacrifice and commitment to national duty. They take the duty of dying for the nation (identified with men before) from men and gives this holy duty to women as the emblems of the new nation. Women are accepted into public and political life as genderless or deprived of their femininity. Women also have the same rights with men to share national feelings or duties. Both use motherly figures to underscore the desexualized profile of their woman characters personifying the nation and participating in the national struggle. They inspire the idea of sacrifice for the nation by putting personal choices or feelings into the second place. During the social struggle and national war individual desires are suppressed in national myths and allegories to ensure that individuals fight for the nation with their whole self and do not deviate from national goals.

Halide Edib and Lady Gregory, who acquired an anti-imperial perspective by transnational exchanges and international influences, helped recover the social imagination of their nations and showed their reaction to the dominant order or imperial authority through literary revivals and social reforms. They supported the view of a return to the local language, history and native culture, promoted their international outlook of anti-imperialism by challenging patriarchy, colonial activities, and cultural imperialism, and masculinized national discourses of their period. Sharing the great responsibility of intellectuals striving to elevate the dignity of their nations with cultural revivals, literary works, and 
The cultural nationalism of Halide Edib Adivar and Lady Augusta Gregory from the aspects of gender, language and antiimperialism / N. G. Albay (pp. 469-494)

social transformation, Adıvar and Gregory shaped their views on nationalism through their crosscultural travels, observations and interactions with prominent national leaders. These international connections enabled them to be informed about the current social and political occasions of their period as well as to encounter leading feminists, philosophers or political leaders worldwide.

Adıvar and Gregory address to global issues or problems with their radical views, actions or roles they played in their local circles. Thanks to national self-study, they reach better understanding of other peoples and nations while their international connections reinforce their sense of nationalism and aroused their curiosity in the inner meaning of nationalism. They moved from the particular to the universal in terms of theme, vision and social actions. While the Egyptian anti-colonial resistance influenced Gregory, Adivar was greatly influenced by Indian anti-colonial resistance, which refers to their connections with the Eastern world inspiring them with the idea of anti-imperialism. Indian and Egyptian examples of anti-colonial struggle enabled both writers to draw parallels and interrogate anticolonial nationalisms actively engaged in India, Irish, Turkey and Egypt during the early twentieth century. In Gregory and Adivar's adoption of an international outlook of anti-imperialism, these examples of anti-colonial resistance were influential and this interaction helped them to appreciate their own culture, history and traditions more and more. Having a universal sense of anti-imperialism, Gregory and Adıvar were liberal in the politics of their own country, while they were internationalists in their outlook upon world affairs. Their fundamental interests were not in politics, but in the cultural heritage of their nations, under the fascination of Irish and Anatolian peasantry. Adivar and Gregory searched for different ways to declare their national identity and self-determination to imperial powers through their multi-dimensional identity as independent rebellious nationalists. Their opposition to authority carried them to the same political platform in a turbulent period of cultural nationalism and political activism. They made a criticism of patriarchal authority, imperial ideologies in their local and international circles under the inspiration of their cultural attainments, nationalist and feminist spirit and anti-imperial perspectives. They achieved to gain recognition both nationally and internationally because of their egalitarian and liberalistic outlook on human values and anti-imperialist way of thinking against colonization, occupation or invasion.

\section{Bibliography}

Adak, H. (2004). “An epic for peace (Introduction to Halide Edib's Memoirs)”, in Memoirs of Halide Edip, Istanbul, Gorgias Press.

Adak, H. (2003). "National Myths and Self-Narrations: Mustafa Kemal's Nutuk and Halide Edip's Memoirs and the Turkish Ordeal”, South Atlantic Quarterly, Vol.102, no. 2/3, 509.

Adak, H. (2004). Otobiyografik Benliğin Çok-Karakterlilĭ̆i: Halide Edib’in İlk Romanlarında Toplumsal Cinsiyet, İstanbul:İletişim.

Adıvar, H. E. (2007). Ateşten Gömlek, İstanbul, Can.

Adıvar, H. E. (1922). Conflict of East and West in Turkey, Lahore, Ripon Press. (Delhi: Maktaba Jamia Millia Islamia, 1929.)

Adıvar, H. E. (1944). “Edebiyatta Tercümenin Rolü”, Edebiyatta Tercümenin Rolü, (1942-43 Üniversite Konferanslarından Ayrı Bası), Istanbul : Kenan Matbaası.

Adıvar, H. E. (2007). Handan, İstanbul : Can.

Adıvar, H. E. (2014). Hindistan'a Dair, İstanbul : Can.

Adıvar, H. E. (1968). Kenan Cobanlart-Maske ve Ruh, İstanbul : Atlas Kitabevi.

Adıvar, H. E. (1926). Memoirs of Halide Edib, London, Lightning Source UK Ltd. 
Adıvar, H. E. (2007/2011). Mor Salkıml Ev, İstanbul : Can.

Adıvar, H. E. (1967). Raikin Annesi, Atlas Kitabevi.

Adıvar, H. E. (2007). Sinekli Bakkal, İstanbul : Can.

Adıvar, H. E. (2009). Tatarcek, İstanbul : Can.

Adıvar, H. E. (1930). Turkey Faces West, London : Yale University Press.

Adıvar, H. E. (1928). The Turkish Ordeal: Being the Further Memoirs of Halide Edip, New York, London, The Century Co.

Adıvar, H. E. (2011). Türkün Ateşle İmtihanı: Kurtuluş Savaşı Anıları, 6th ed. İstanbul : Can.

Bell, C. O. (2008). "Being Ireland: Lady Gregory in Cathleen ni Houlihan", The Ohio State University, Master's Diss.

Deane, S. (1985). Celtic Revivals: Essays in Modern Irish Literature 1880-1980, Boston, faber and faber.

Durakbaşa, A. (2000). Halide Edib: Türk Modernleşmesi ve Feminizm, İstanbul: İletişim.

Ellis-Fermor, U. (1954). The Irish Dramatic Movement, $2^{\text {nd }}$ edn, London : Methuen.

Enginün, İ. (2007). Halide Edip Adıvar'in Eserlerinde Doğu ve Batı Meselesi, İstanbul:Dergah.

Enloe, C. (1989). Bananas, Beaches and Bases. Making Feminist Sense of International Politics, Berkeley, University of California Press.

Fogliani, M. (2014). "Lady Gregory: Exalting Folklore and Dialect as National Identity", Journal of Italian Literature and Culture: La Fusta Devotion, Volume XXII.

Göknar, E. (2013). “Turkish Islamic Feminism Confronts National Patriarchy: Halide’s Divided Self”, Journal of Middle East Women's Studies 9(2).

Graham, B. (1997). In Search of Ireland: A Cultural Geography, London : Routledge.

Gregory, I. A. (1882). Arabi and His Household, London : Kegan Paul, Trench.

Gregory, I. A. (1970). Cuchulain of Muirthemne: The Story of the Red Branch of Ulster. Gerrards Cross, Colin Smythe.

Gregory, I. A. (1983). "Devorgilla”, Selected Plays. Gerrards Cross, Colin Smythe.

Gregory, I. A. (1918). Gaol Gate, Dublin : Talbot Press.

Gregory, I. A. (1912). Irish Folk History Plays, New York and London: G.P. Putnam's sons <http://www.archive.org/details/irishfolkhistoryo2gregrich

Gregory, Isabella Augusta. (1972). Our Irish Theatre, Gerrards Cross, Colin Smythe.

Gregory, Isabella Augusta. (1995). Lady Gregory: Selected Writings, edited by Lucy McDiarmid and Maureen Waters, London : Penguin Books.

Gregory, I. A. (1915). Seven Short Plays, New York : G.P. Putnam's Sons.

Gregory, I. A. (1974). Seventy Years: 1852-1922, Edited by Colin Smythe, New York : Macmillan.

Gregory, I. A. (1971). The Collected Plays, II, The Tragedies and Tragic-Comedies, edited by Ann Saddlemyer, Gerrards Cross, Colin Smythe and Irish University Press.

Gregory, I. A. (1924). The Story Brought By Brigit: A Passion Play In Three Acts, London, G.P.Putnam's and Sons.

Gregory, I. A. (1922). Three Wonder Plays. The Dragon; Aristotle's Bellows; The Jester, New York: Putnam's.

Hepçilingirler, FeFyza. (2017). Halide Edip Adıvar: Halka Doğru- Büyük Mecmua (1919) ve Yedigün (1936-1939) Yazıları. İstanbul: Can. 
The cultural nationalism of Halide Edib Adivar and Lady Augusta Gregory from the aspects of gender, language and antiimperialism / N. G. Albay (pp. 469-494)

Hill, J. (2011). Lady Gregory: An Irish Life, Cork, the Collins Press.

Howe, S. (2004). Ireland and Empire: Colonial Legacies in Irish History and Culture, Oxford : Oxford University Press.

Inglis, D \& Almila, A.-M. (Eds). (2016). the SAGE Handbook of Sociology, London : SAGE.

Jayawardena, K. (1986). Feminism and Nationalism in the Third World, London : Zed Books Ltd.

Kiberd, D. (1996). Inventing Ireland: The Literature of the Modern Nation, London : Vintage.

Kitchen, J. E.; Miller, A. and Rowe, L. (2011). Other Combatants, Other Fronts: Competing Histories of the First World War, Newcastle upon Tyne : Cambridge Scholars Publishing.

Kopper, E, A. (1976). Lady Isabella Persse Gregory, Boston : Twayne Publishers.

Lejeune, P. (1982). "The Autobiographical Contract", Todorov, Tzvetan, ed. French Literary Theory Today: A Reader, Çev. R. Carter, Cambridge : Cambridge University Press.

McDiarmid, L. (1994). 'Augusta Gregory, Bernard Shaw, and the Shewing-Up of Dublin Castle', Publications of the Modern Language Association, 109.1, pp. 26-44 (1995) and Maureen Waters Eds, Lady Gregory: Selected Writings, Harmondsworth : Penguin.

McMahon, G. T. (2008). Grand Opportunity: The Gaelic Revival and Irish Society, 1893-1910, New York : Syracuse University Press.

Murray, C. (1997). Twentieth-Century Irish Drama: Mirror Up To Nation, Manchester : Manchester University Press.

Parla, J. (2008). 'The Wounded Tongue: Turkey's Language Reform and the Canonicity of the Novel', $P M L A$, vol. 123, No.1, pp. 27-40.

Sönmez, E. (1973). “The Novelist Halide Edip Adıvar and Turkish Feminism”, Welt Des Islams, No. 14, pp. 81-115.

Ward, M. (1983). Unmanageable Revolutionaries: Women and Irish Nationalism, London : Brandon.

Wilson, C. (2006). "Representations of Women in the Abbey Theatre", Charleston SC, Chrestomathy, Vol. 5 .

Wilmer, S. (2009). “Theatrical Nationalism: Exposing the "Obscene Superego" of the System", Journal of Dramatic Theory and Criticism.

Yeats, W. B. (1989). "Letters to the New Island", In the Collected Works of W.B. Yeats, Vol VII. Eds. George Bornstein and Hugh Witmeyer, New York : Macmillan.

Yeats, W. B. (2002). Writings on Irish Folklore, Legend and Myth, Penguin Classics. 